\title{
Improvement of Technology for Increase of Rolling Resistance of Rock Excavator Shafts
}

\author{
S.Q. Atakhonova* \\ Andijan Machine Building Institute, Uzbekistan
}

*Corresponding Author: S.Q. Atakhonova, Andijan Machine Building Institute, Uzbekistan

\begin{abstract}
This article discusses the process of improving the 3K4: D320 / $503 K .4316190$ mining excavator roller resilience technology. A scientific and practical approach is taken to increase the wear resistance of the excavator shaft and extend its lifespan properties. Expedition of steel-resistant steel was made in "Andijonmash OAJ" (In Uzbekistan) factory and put into production.
\end{abstract}

Keywords: engraving, rigging, special-purpose steel, coalmine, geological mine, reserve, underground gas, flux, kaolin, ore, slag, rig.

\section{INTRODUCTION}

Nowadays, it is important to create new content of domestic production, to increase the national economy with efficient and economically improved production techniques.

One of the important tasks in this area is to carry out targeted scientific research, including: - Metal structure management at metalworking companies, providing high quality steel products, providing high quality products;Development of technology for the production of corrosion resistant stainless steel; - improving the theoretical and technological foundations of technological processes contributing to enhancing the properties of metals; the creation and production of new metal special steel steel with energy and material savings based on the latest advances in science and technology, saving economies and productivity while creating unique custom steel.

For many years, JSC "Andijanmash" produced and exported excavator straps 3K4: D320 / 50 3K.4316190 from the 40X mark for Angiren coal deposit. Chemical composition of 40X steel C (0.36-0.44), Si (0.17-0.37), Mn (0.5-0.8), Ni 0.3, C (0.035), P (0.035), X (0.8-1.1), Cu (0.3). Angren coal deposit is a brown coal mine in the Akhangaran valley of Tashkent region. At the foot of the Kurama and Chatkal mountains. Geological prospecting began in 1934. The first mine was launch in 1940. The area of the coal basin is about $70 \mathrm{~km}^{2}$. The proved reserves are 1.9 billion $\mathrm{m}$ to $860 \mathrm{~m}$ depth. $\mathrm{t}$ (about $1 / 4$ of all coal reserves in Central Asia). Coal is found in the midst of coal beds and is very fertile, with thickness from $20 \mathrm{~m}$ to $130 \mathrm{~m}$ at the surface. Coal is brand B2. Combustion heat is $13.9 \mathrm{MJ} / \mathrm{kg}$. Coal is mainly mined by open pit ( 2.5 million tons), partly underground ( 0.5 million tons).

In addition, the gas at the Underground Gas Station will be convert to coal, amounting to 50 million cubic meters per year. $\mathrm{m}^{3}$ of gas will be produced. In addition to coal, kaolin is also mine. Most layers are used for the production of Portland cement, flux, burt and raw material for sewage pipes production.

\section{RESEARCH METHOD}

Methodical part1. Addition of iron-fixing elements in iron solution to changes in the chemical composition of metals from the methods of increasing the wear resistance of excavator $3 \mathrm{k} 4: 320$, 3K4316190

2. Detection of Te and Mn by grinding pressure in vacuum ovens at 1100 degrees by grinding the powder into ball mills.

3. There are various technological processes, such as covering different types of coatings on the working surface of the excavator strap.

International Journal of Research Studies in Electrical and Electronics Engineering (IJRSEEE) Page | 9 
In the preparation of $110 \mathrm{G} 13 \mathrm{~L}$ steel by the method of legalizing steel in the conditions of "Andijanmash" JSC in July 2018, C 0.9-1.4\% Si $0.8-0.1 \%$ Mn 11.5-15 Ni 1\%, S 0.05\% P $0.12-1 \%$ $\mathrm{Cu} 0.3 \% \mathrm{Fe} 83 \%$ Chemical composition and the secretion of edible resistant steel by the addition of manganese in $13 \%$ powder solution.

The mechanical properties of the 3K4: D320 / 50-3K.4316190 excavator strap made of steel 110G13L are increased by 2 times. 110G13L Stainless steel HB 186-229 Mpa. The following basic technological operations for the production of excavator straps are as follows: Selection and manufacture of batch materials; calculation of materials; excavator shaft drawing; excavator unit modeling; preparation of molding materials for casting; removal of the cast.

Removable metal in the form of "cast ironwork - working cast" consists of these special properties. The main advantage of this type of steels is that of extruding steel, which extends the lifespan of the metal and reduces the volume of excavator straps.

We chose the Induction Furnace to pour this detail. Induction steel smelting furnace (1450 kilns steel $1520^{\circ} \mathrm{C}$, density $\left.7900 \mathrm{~kg} / \mathrm{m}^{3}\right)$. The induction furnace is an electrothermal device for metal liquefaction. The band and channel I. are used. Tigel Induction oven consists of an inductor and a tigel consisting of a solenoid made of tubes. There are open, vacuum, gas-filled and compression types. Depending on the liquefied material, tigel ceramic materials, graphite, steel, etc. $\mathrm{k}$. It is made from the volume ranges from a few $\mathrm{kg}$ to several $\mathrm{t}$. The oven operates with low, medium and high frequency currents. In the induction furnace, steel, iron, copper, aluminum, magnesium and precious metals are dilute.

Duct Induction Oven Main parts: thawing tub, magnetic core, inductor, base stone. In this induction furnace, the electromagnetic energy is convert into thermal energy in the condensed channel. It contains non-ferrous metals and their alloys, liquefaction. One to several hundred kg how many t. Duct Induction Oven is powered by industrial frequency. The method of induction heating in induction furnaces, that is, electric current caused by a variable electromagnetic field, has been used. [1]

\section{RESULTS AND DISCUSSION}

The expedition for the production of glue-resistant poachers was carried out in Uzbekistan and was put into operation in Andijanmash. These studies have shown that local production of 110G13L stainless steel, including $13 \%$ of manganese in the fabrication of structural steel, has also had a positive effect on the corrosion and erosion effects of the metal. The technology for the production of stainless steel110G13L steel for maneuvering, drilling and excavator straps. The analysis of the mechanism of formation of compounds and the specificity of the new alloys obtained for different devices allows predicting the technological process and the selection of the technological conditions of the impregnation elements. The chemical composition of the stainless steel of $110 \mathrm{G} 13 \mathrm{~L}$ is $\mathrm{C} 0.9-1.4 \% \mathrm{Si}$ $0.8-0.1 \%$ Mn 11.5-15 Ni 1\%, C 0.05\% P $0.12-1 \%$ Cu0.3\% Fe 83\%. Manufactured of excavated tires, train rails. Figure 1 above shows that the Angren coal deposit in the Akhangaran valley of the Tashkent region is located at the foot of the Kurama and Chatkal mountains, where excavator blades are allowed to be eaten according to operating conditions. Resistant, corrosion resistant, hard and adhesive. 110G13L stainless steel increases carbon hardness, copper adhesive viscosity, manganese resilience, and nickel corrosion resistance.

\section{ANDIZHAN MACHINE PLANT}

3K4: 3K9: D320 / 50: D800 / 57: 8K12: CNS-60.180

\section{ROTAR EXCOVATOR BUKKET TOUTH 3K.4316190}

Designed to soften and increase the cultural soil Material steel 110G13L

Overall dimensions $485 \times 180 \times 105$

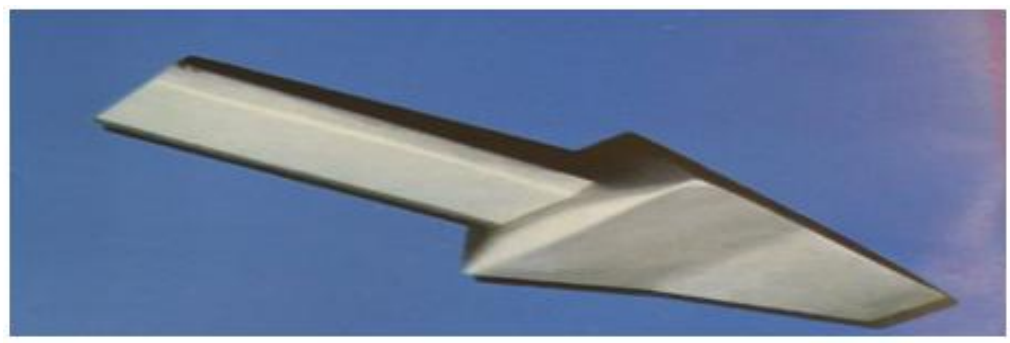

Figure 2 


\section{CONCLUSION}

The expedition for the production of glue-resistant poachers was carried out in Uzbekistan and was put into operation in Andijanmash. These studies have shown that the local production of 110G13L stainless steel, including $13 \%$ of manganese in the fabrication of structural steel, had a positive effect on the corrosion and erosion effects of the metal.

The technology for obtaining steel steel 1101G13L has been developed. The analysis of the mechanism of formation of compounds and the specificity of the new alloys obtained for different devices allows predicting the technological process and the selection of the technological conditions of the impregnation elements. The chemical composition of the stainless steel of 110G13L is C 0.91.4\% Si 0.8-0.1\% Mn 11.5-15 Ni 1\%, C 0.05\% P 0.12 -1\% Cu0.3\% Fe 83\%.

Manufactured of excavated tires, train rails. Figure 1 above shows that the Angren coal deposit in the Akhangaran valley of the Tashkent region is located at the foot of the Kurama and Chatkal mountains, where excavator blades are allowed to be eaten according to operating conditions. Resistant, corrosion resistant, hard and adhesive. 110G13L stainless steel increases carbon hardness, copper adhesive viscosity, manganese resilience, and nickel corrosion resistance.

Mechanical properties of steel castings $110 \mathrm{G} 13 \mathrm{~L}$ at various test temperatures

\begin{tabular}{|c|c|c|c|c|c|c|}
\hline $\begin{array}{c}\text { Test } \\
\text { temperature }\end{array}$ & $\sigma 0,2(\mathrm{MПа)}$ & бв(МПа) & $\delta 5(\%)$ & $\psi \%$ & KCU (Дж/см2) & НВ \\
\hline 20 & $360-380$ & $654-830$ & $34-53$ & $34-43$ & $260-350$ & $186-229$ \\
-20 & & & & & $240-320$ & $20-300$ \\
-40 & & & & & $190-300$ & \\
-60 & & & & & $90-210$ & \\
-80 & & & & & \\
\hline
\end{tabular}

Conclusion In conclusion, reliable and sufficiently high-quality steel forming of the working element by means of self-casting of excavator type 3K4: D320 / 50 3K.4316190 for the Angiren coal deposit $110 \mathrm{G} 13$ steel the technological basis of the preparation is developed. Figure 2 shows the size of the excavator strap 3K4: D320 / 50 3K.4316190. The high results achieved were important in obtaining edible steels.

\section{REFERENCES}

[1] Norkhudjaev F. R. Современное состояние проблемы металлических слоиствых композиции (CEC) // III Международная научно-практическая Conference: «Современные материалы, техника и технологии в машиностроениі» посвященная 20 лет АО «Узавтосаноаt» и 5 летёю Андижу. Save the state. 19-21 April 2016 goda.- Andijan.- S.270-275.

[2] Umarov E.O. Textbook

[3] Wikipedia, the free encyclopedia Jump to navigation Jump to search

[4] AA Zangiev, GP Lyshko, AI Scorokhodov. Производственная exploitation machinery-tractornogo parka. M., Kolos, 1996.

[5] AK Igamberdiev and others Collection of lectures on the use of machine-tractor fleet. T., TIMSMI, 2002.

[6] NK Vodolazov. "Kursovoye I Diploma Projections in Mechanization of Selection Services" Moscow. VO "Agropromzdat" 1991 г.

Citation: S.Q. Atakhonova, (2020). “ Improvement of Technology for Increase of Rolling Resistance of Rock Excavator Shafts”. International Journal of Research Studies in Electrical and Electronics Engineering (IJRSEEE), 6(1), pp 9-11. DOI: http://dx.doi. org/10.20431/2454-9436.0601002

Copyright: (C) 2020 Authors. This is an open-access article distributed under the terms of the Creative Commons Attribution License, which permits unrestricted use, distribution, and reproduction in any medium, provided the original author and source are credited. 